DOI: 10.17707/AgricultForest.61.1.10

\author{
Suzan ALTINOK, Engin YURTSEVEN, \\ Sertan AVCI, Hasan S. ÖZTÜRK, M. Fatih SELENAY ${ }^{1}$
}

\title{
THE EFFECTS OF DIFFERENT IRRIGATION WATER SALINITIES AND LEACHING RATIOS ON GREEN AND DRY FORAGE YIELDS OF ALFALFA (Medicago sativa L.)
}

\begin{abstract}
This study was executed to describe the impact of irrigation water quality and leaching fractions on drainage water quality and soil profile salinity in lizimeter conditions with alfalfa (Medicago sativa) cv. Elci. The experiments were conducted with 3 irrigation water salinities $(0.25,1.5$ and $3 \mathrm{dS} / \mathrm{m})$ using $\mathrm{NaCl}$ and $\mathrm{CaCl}_{2}$ salts and 4 irrigation volume concluded leaching $(10 \%, 20 \%$, $35 \%$ and $50 \%$ more water than required) with 3 replications in fully randomized experimental design in the years of 2010 and 2011.

The experiment was set up using plastic pods made by cutting from $6 \mathrm{~m}$ long waste-water pipes, and each was $115 \mathrm{~cm}$ long and $40 \mathrm{~cm}$ diameter, located as outdoor lysimeters system at the Ankara University Agricultural Faculty experimental field. Alfalfa seeded to each pod and they were cut 5 times for each year for green and dry forage yields. First year 10, second year totally 6 irrigation applications were performed and for every irrigation, the drainage water which run out from the lizimeters, were collected and analysed by salinity criteria's. The soil samples were taken in different depth and analysed to describe soil profile salinization affect, and daily evaporation and other meteorological data were collected to determine plant water use states as well.

At the result, there were no any significant effects of the salinity on irrigation water and leaching ratio on total green and dry forage yields of alfalfa plants as average over the 5 cuts, in both years. But, the total effects of the salinity on irrigation water and leaching ratio were significant for some cut on green and dry forage yields of alfalfa.
\end{abstract}

Keywords: Alfalfa, irrigation water salinities, leaching ratio, green forage yield, dry forage yield.

\section{INTRODUCTION}

Usage of high salt content drainage water during irrigation will cause accumulation of salts in the soil (Yurtseven and Orta, 1992). Primary

\footnotetext{
${ }^{1}$ Suzan Altınok (corresponding author: altinok_s@yahoo.com), Ankara University, Dept. Field Crops, Dışkapı, Ankara, Turkey; Engin Yurtseven, Sertan Avc1, Fatih Selenay, Ankara University, Dept, Farm Structures and Irrigation, Dışkap1, Ankara, Turkey; Hasan S. Öztürk3 M., Ankara University, Dept, Soil Science and Plant Nutrition, Dışkap1, Ankara, Turkey.
}

Paper presented at the $5^{\text {th }}$ International Scientific Agricultural Symposium "AGROSYM 2014".

Notes: The authors declare that they have no conflicts of interest. Authorship Form signed online. 
requirements for a successful water management are to reduce the amount of irrigation water applied and re-use of drainage water. It is known that a large portion of irrigation water applied (usually 50\%) not absorbed by the plant, but removed as drainage water (Frederiksen, 1992). Reducing the rate of leaching and improving irrigation efficiency increases salinity level at and under the root zone and reduction in drainage water salt level (Oster and Rhoades, 1978).

Alfalfa is a main fodder crop in many countries and is a moderately salttolerant crop. It is susceptible to salt damage during its establishment (Lehman and Robinson, 1979; Stone et al., 1979). Dirksen (1985) looked at the relationship between root uptake weighted mean soil water salinity and total leaf water potential of alfalfa. He found that under most field conditions plants interact and adjust to water contents and salinity that varied in time and space. According to El-Nakhlawy et al. (2012) as salinity levels increased, cumulative fresh and dry forage yield and plant height significantly decreased in their research on alfalfa genotypes.

Agricultural production in arid and semi-arid regions is mainly based on irrigation. Because of that, the objective of our research to assess the effects of different irrigation water salinities and leaching ratios on green and dry forage yields of alfalfa (Medicago sativa L.) cv. Elçi into lysimeters conditions.

\section{MATERIAL AND METHODS}

In this experiment, the seeds of alfalfa cultivar "Elci" were used as a material. The experiments were conducted in PVC lysimeters $(115 \mathrm{~cm}$ in long and $40 \mathrm{~cm}$ in diameter) cultivated with alfalfa in field conditions. Three different irrigation water salinity ( $\mathrm{S} 1, \mathrm{~S} 2$, and $\mathrm{S} 3$, and $0.25,1.5$ and $3.0 \mathrm{dS} / \mathrm{m}$ respectively) and four leaching ratio (LR1, LR2, LR3, LR4 and 10\%, 20\%, 35\% and 50\% more water than required, respectively) levels were used in an randomized factorial design experiment with three replications in totally 36 lysimeters. Lysimeters are located in the experimental fields of Ankara University, Faculty of Agriculture, Dışkapi; Ankara. According to State Meteorology Department, long-term observations (1975-2010) in Ankara showed that average precipitation, mean temperature and relative humidity were $403 \mathrm{~mm}$ year $^{-1}, 12.1^{\circ} \mathrm{C}$ and $61 \%$, respectively. Corresponding values in 2010 were $594 \mathrm{~mm}, 14.5^{\circ} \mathrm{C}$ and $59 \%$, however they were $436 \mathrm{~mm}, 12^{\circ} \mathrm{C}$ and $62 \%$ in 2011 . Test soil is sandy-clay-loam (SCL) with $58 \%$ sand, $21 \%$ silt and $21 \%$ clay.

Irrigation times were determined in relation to plant vegetative development and harvest dates. Averagely, irrigation water was applied 2-3 times in a month depending on the climatic conditions. Leaching ratio was defined in this study as the ratio of the volume of drainage water to the volume of irrigation water (Ayers and Westcot, 1989). Experiments carried out during April to October in 2010 and 2011. During the vegetation period, 10 irrigations in 2010 and 6 irrigations in 2011 were done. The drainage water which run out from the lizimeters, were collected and analysed by salinity criteria's. Alfalfa plants were cut 5 times at the beginning of flowering for both years. Green forage yield were 
calculated for each pod and samples were dried in ovens at $70^{\circ} \mathrm{C}$ to a constant weight for dry matter content (Martin et al., 1990). For the preparation of saline irrigation water $(0.25,1.5$ and $3.0 \mathrm{dS} / \mathrm{m}), \mathrm{NaCl}$ and $\mathrm{CaCl}_{2}$ salts were used. These salts were selected because they are common in for salt stress in natural and artificial rearing environments (Turhan and Baser, 2001).

\section{RESULTS AND DISCUSSION}

Alfalfa was cut five times at the beginning of flowering stage in both years. Green and dry forage yields (g/pods) were calculated for each cut as well as total yields. The results of variance analysis as significance level on green and dry forage yields for water salinities and leaching ratio of alfalfa were given in Table 1 for both years.

According to Table 1 there were no significant water salinities and leaching ratio effects in total green and dry forage yields as averaged over the 5 cuts in both years. In another term, total green and dry forage yields did not change with different water salinities and leaching ratios. However, on the green and dry forage yields for 3rd cut, significant differences $(\mathrm{P}<0.05)$ were observed among the leaching ratios in 2010. In 2011, green forage yields of 3rd and 5th cut were differed significantly in terms of water salinities as well as dry forage yield of 5 th cut $(\mathrm{P}<0.05)$.

Table 1 . The effects of water salinities and leaching ratio on green and dry forage yields of alfalfa (g/pod) in 2010 and 2011.

\begin{tabular}{|c|c|c|c|c|c|c|}
\hline \multirow[t]{2}{*}{ Year } & \multicolumn{6}{|c|}{$\begin{array}{c}2010^{1} \text { and } 2011^{2} \\
\text { Green Forage Yield }\end{array}$} \\
\hline & 1 st Cut & 2nd Cut & $3 \mathrm{rd} \mathrm{Cut}$ & 4th Cut & 5th Cut & Total Cuts \\
\hline Water Salinities & N.S. ${ }^{1}$ and 2 & N.S. & N.S. and $*$ & N.S. & N.S. and $*$ & N.S. \\
\hline Leaching Ratio & N.S. & N.S. & $*$ and N.S. & N.S. & N.S. & N.S. \\
\hline İnt. & N.S. & N.S. & N.S & N.S. & N.S. & N.S. \\
\hline \multirow[t]{2}{*}{ Year } & \multicolumn{6}{|c|}{$\begin{array}{l}2010^{1} \text { and } 2011^{2} \\
\text { Dry Forage Yield }\end{array}$} \\
\hline & 1 st Cut & 2nd Cut & 3rd Cut & 4th Cut & 5th Cut & Total Cuts \\
\hline Water Salinities & N.S. ${ }^{1}$ and 2 & N.S. & N.S. & N.S. & N.S. and & N.S. \\
\hline Leaching Ratio & N.S. & N.S. & $*$ and N.S. & N.S. & N.S. & N.S. \\
\hline İnt. & N.S. & N.S. & N.S. and * & N.S. and * & N.S. & N.S. \\
\hline
\end{tabular}

*,** Significant at $\mathrm{P}<0.05$ and $\mathrm{P}<0.01$ levels, respectively, N.S: Not Significant

In terms of Duncan results, the forage yields were decreased with the increasing of leaching ratio in 3rd cut of 2010 (Table 2). Green forage yields were increased with increasing of water salinity doses in 3rd cut of 2011 as well. However, the green and dry forage yields were decreased with increasing of water salinities in 5th cut which is expected (Table 2.). 
Table 2. Green and dry forage yields of alfalfa (g/pod) on different leaching ratio and water salinities.

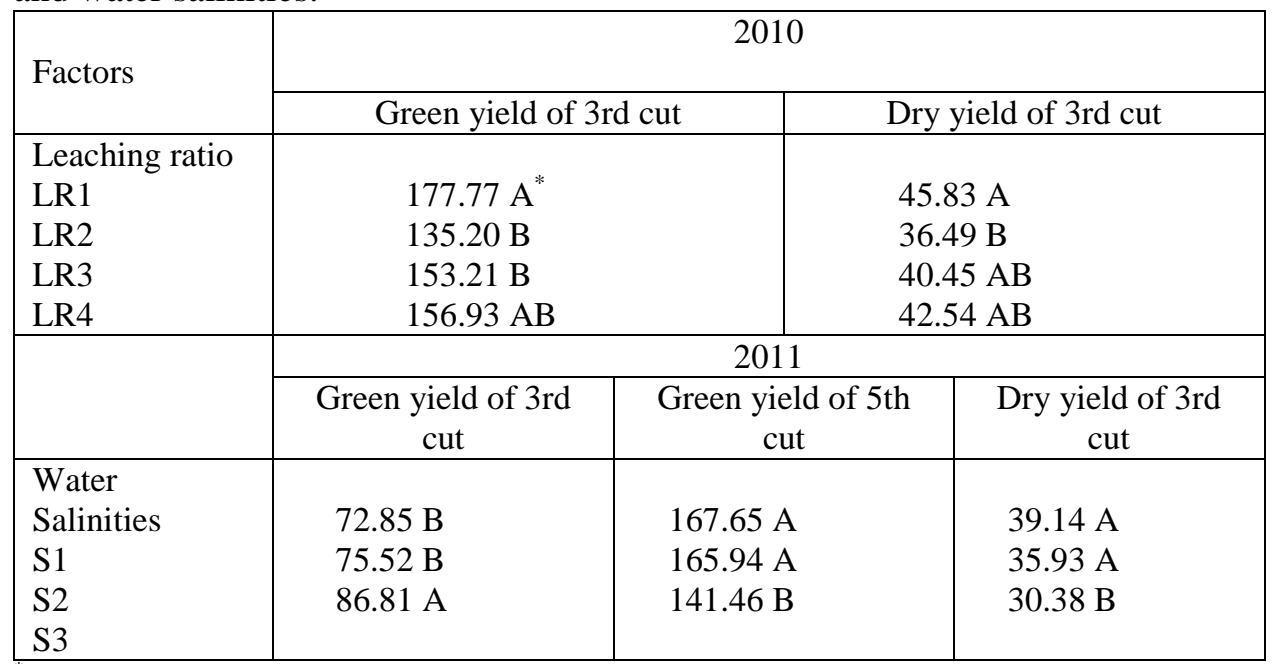

"Means of each cut results in a column followed by the same upper case letters are not significantly different according to Duncan's Multible Range Test.

In 2011, significant interactions were obtained between water salinities and leaching ratios in dry forage yields of 3rd and 4th cuts. Interactions were shown Figure 1 and 2. These mean is the dry forage yields differed with the total effects of water salinities and leaching ratios.

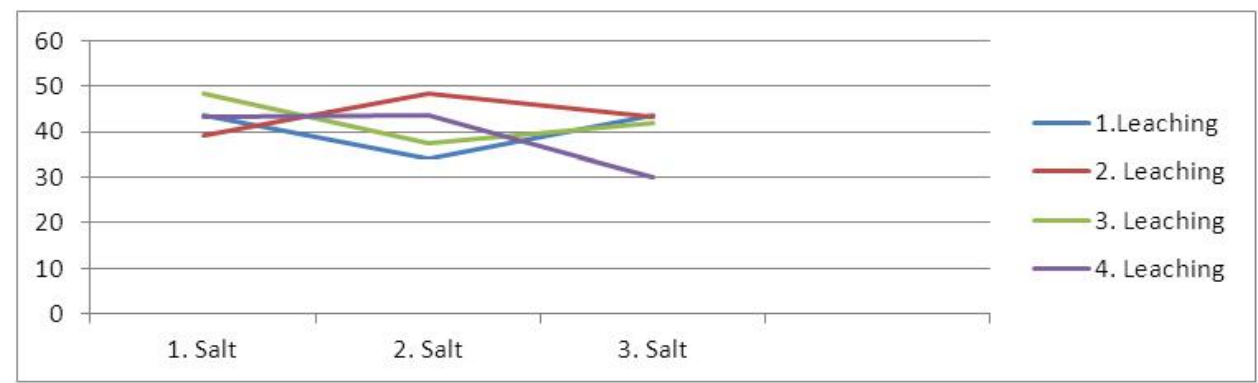

Figure 1. Representation of water salinities and leaching ratio interactions in 3rd cut dry forage yield of alfalfa in 2011.

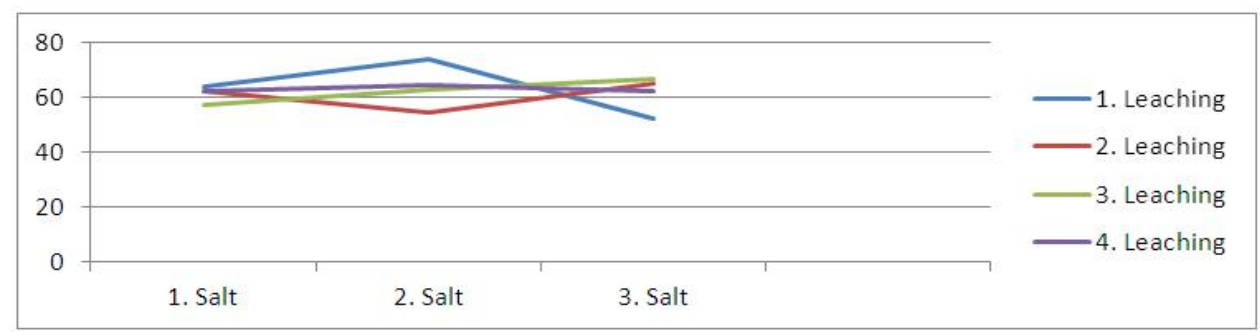

Figure 2. Representation of water salinities and leaching ratio interactions in 4th cut dry forage yield of alfalfa in 2011. 
El-Nakhlawy et al. (2012) searched that the effects of 3 irrigation water salinity levels, $1.875,6.250$ and $12.500 \mathrm{dS} \mathrm{m}(-1)$ on four alfalfa genotypes concerning cumulative fresh and dry forage yields over 36 cuts during 2008, 2009 and 2010. At the result they found that when the salinity levels increased, cumulative fresh and dry forage yield and plant height significantly decreased as we mostly had in our research. Alfalfa is susceptible to salt damage during its establishment (Lehman and Robinson, 1979; Stone et al., 1979). Alfalfa yield is influenced by salinity by Alva (1985). In another study Dirksen (1985) looked at the relationship between root uptakes weighted mean soil water salinity and total leaf water potential of alfalfa. He found that under most field conditions plants interact and adjust to water contents and salinity that varied in time and space. It depends soil and climatic conditions likely in our research. No water salinities and leaching ratio effects on total green and dry matter yields showed this effectiveness. Total alfalfa yield of both years shows that it has not too low tolerance to salinities and leaching ratio as a perennial plant (Ayers and Westcot, 1989), in addition it is known from soil salinity data that as low as $10 \%$ leaching fraction was able to reduce salinity since the experimental soil is sandy.

\section{CONCLUSIONS}

The result of this research is that the salinity on irrigation water and leaching ratio did not effect to total green and dry forage yields of alfalfa plants as average over the 5 cuts, in both years. But, the combination effects of the salinity on irrigation water and leaching ratio were significant for some cuts on green and dry forage yields of alfalfa.

\section{REFERENCES}

Alva, A.K. (1985). A comparison of fertilizer recommendations by soil testing program and alfalfa yield response in soils of two associations. Soil Sci. Plant Anal., 6 (2).

Ayers, R.S., Westcot, D.W. (1989). Water quality for agriculture. FAO Irrigation and Drainage Paper 29, Rome.

Dirksen, C. (1985). Relationship between root uptake-weighted mean soil water salinity and total leaf water potentials of Alfalfa. Irrig. Sci., 6, pp. 39-50.

El-Nakhlawy, FS, Shaheen, MA, Al-Shareef, AR (2012). Response of forage yield, protein and proline contents of alfalfa genotypes to irrigation water salinity and phosphorus fertilizer Journal Of Food Agriculture \& Envıronment; Jan, 10; 1; p551-p557.

Frederikson, Harald D. (1992). Water Resources Institutions: Some Principles and Practices, Technical Paper No: 191, The World Bank, Washington, DC.

Lehman, F.E., Robinson, (1979). Progress in developing salt tolerance in Alfalfa. Proc. 9th California Alfalfa Symp. Fresno, CA, 12-13 December, University of California Cooperative Extension Service, Davis, CA.

Martin, R.C., Voldeng, H.D., Smith, D.L. (1990). Intercropping corn and soybean for silage in a cool-temperate region: yield, protein, and economic efects. Field Crops Res. 23:295-310. 
Oster, J.D., Rhoades, J.D. (1978). Calculated drainage water compositions and salit burdens resulting from irrigation with river waters in the Western United States. J. Of Environmental Quality, 4:73-79.

Stone, J.E., Marx, D.B., Dobrenz, A.K. (1979). Interaction of sodium chloride and temperature on germination of two alfalfa cultivars. Agron. J., 75, pp. 425-427.

Turhan, H., Başer, İ. (2001) Toprak Tuzluluğu ve Bitki Gelişimi (Soil salinity and plant development). Akdeniz Üniversitesi Ziraat Fakültesi Dergisi 14(1): 171-179.

Yurtseven, E., Orta, A.H. (1992). Sulama verimliliği ve drenaj hacminin azaltılması (The reduction of water productivity and drainage volume). Topraksu Dergisi, 1(2), 20-23. 